\title{
WORLD MARKET CONDITIONS, GOVERNMENT POLICY AND THE COCONUT INDUSTRY IN THE PHILIPPINES
}

\author{
by \\ Eric L. Hyman, Ph. D ${ }^{1}$
}

\begin{abstract}
The Philippines has the largest planted area of coconuts in the world and this crop provides a significant amount of income and employment for smallholders and landless laborers. Nearly all of the coconut harvested is converted into copra for subsequent processing. The bulk of production is exported as crude coconut oil for industrial uses and copra cake for animal feed. Most of the rest goes into refined, edible oil for the domestic market. The industry is subject to major oscillations in supply and demand from year to year. Production is dominated by large-scale firms currently operating at a low capacity use rate. Real prices may trend downward in the long run due to expanded production from an expansion in the planted area and greater reliance on high-yield varieties, substitution of other oils, and trade policies of importing countries.
\end{abstract}

\section{INTRODUCTION}

This paper begins by discussing the importance of the coconut industry in the Philippines -including the planted area and harvest size, export earnings, and domestic consumption of coconut products. It then covers labour requirements, quality control, and gross revenues to farmers from production of copra. The last section deals with the scale and location of the processing industry.

Planted Area and Crop Size In the Philippines, coconuts are grown on 3.28 million hectares (ha), which is nearly $28 \%$ of the total area planted to agricultural crops. The area devoted to coconuts increased 104\% between 1965 and 1985. The Philippines has the largest planted area in coconuts in the world (UCAP 1986c).

In 1985, 1 ha of coconut land in the Philippines contained an average of 126 trees. This density is low relative to other countries and represents a $16 \%$ decrease over the past two decades as a result of increased spacing to allow interplanting of other crops (Ibid). The average number of trees per hectare varies from 103 to 172 across regions of the country (Valiente et al. 1979).

About 351.32 million coconut trees are now bearing in the Philippines and $85 \%$ of the trees are productive (UCAP 1986c). The rest are immature; senescent; or unproductive due to pests, diseases, thypoon or drought damage, or poor cultural practices (Santos 1986). An average of 30 coconuts ate harvested per tree, resulting in a total of 3,800 nuts per hectare. This yield is low compared to other countries and half of what it could be at maximum productivity (UCAP 1986b; Banzon 1987). The harvest varies considerably from year to year; it was 2.051 million tons (all references to tons pertain to the metric unit of 1,000 kilograms) of copra equivalent in 1985 (figure $1)$.

The contribution of the coconut industry to the gross value added in agricultural crops, has averaged $12 \%$ since 1970, but was only $8 \%$ in 1985 (NEDA 1986). It fluctuates with production and prices of coconuts and competing products. Although the coconut industry's share of gross value added seems low given its proportion of total agricultural land, other crops are often interplanted on the same land and coconut farming requires little effort or cash cost.

\footnotetext{
${ }^{1}$ Program Economist, Appropriate Technology International, Washington, DC USA.
} 


\section{Export Earnings}

Grades and standards exist for coconut product exports from the Philippines (Table 1). Crude oil is the unrefined product of the dry process for oil extraction. Cochin oil refers to a product with a lower free fatty acids (FFA) content and less color than crude oil; e.g., semi-refined and bleached dry process oil or unrefined wet process oil. RBD oil is fully refined, bleached, and deodorized for human consumption. Coconut oil is generally exported as crude or Cochin. Because of the destruction of natural antioxidants, in refined oil, importers would have to do additional refining due to reversion in transport and storage (Banzon 1987). The bulk of crude coconut oil exports; are for industrial purposes rather than edible oil. RBD oil is primarily for the domestic market. Acid oil, a byproduct of refining crude oil, is used in soap.

Moisture content is the most important factor for raw copra exports because it affects the oil yield by weight, storage losses from bacteria and fungal attack, and the degree of refining needed to remove FFA from the oil. Copra cake is the byproduct of pressing copra in an expeller, while copra meal is the residual after solvent extraction. A maximum level of moisture is specified for copra cake and meal since these are sold by weight and water is added to prevent spontaneous combustion.

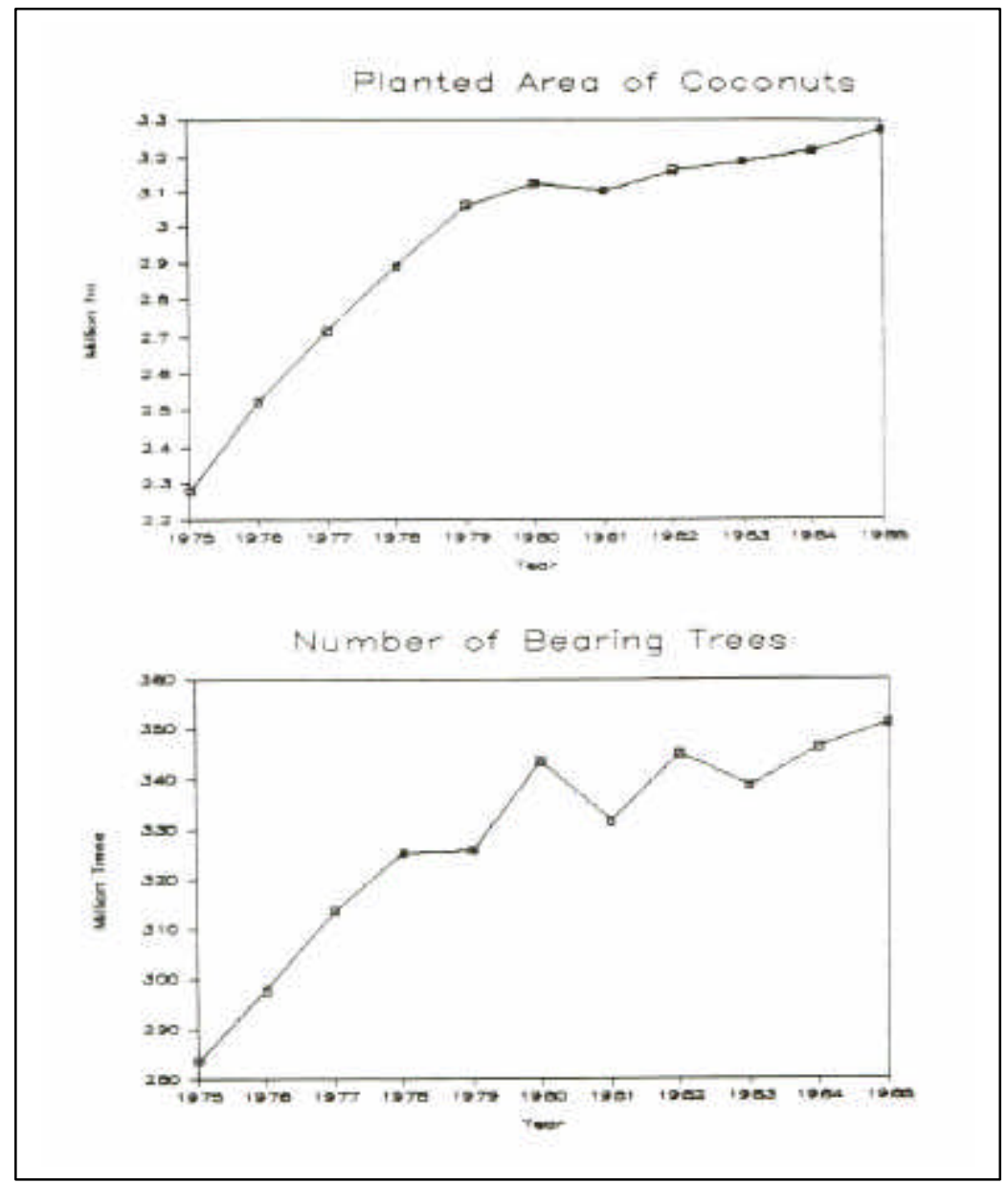




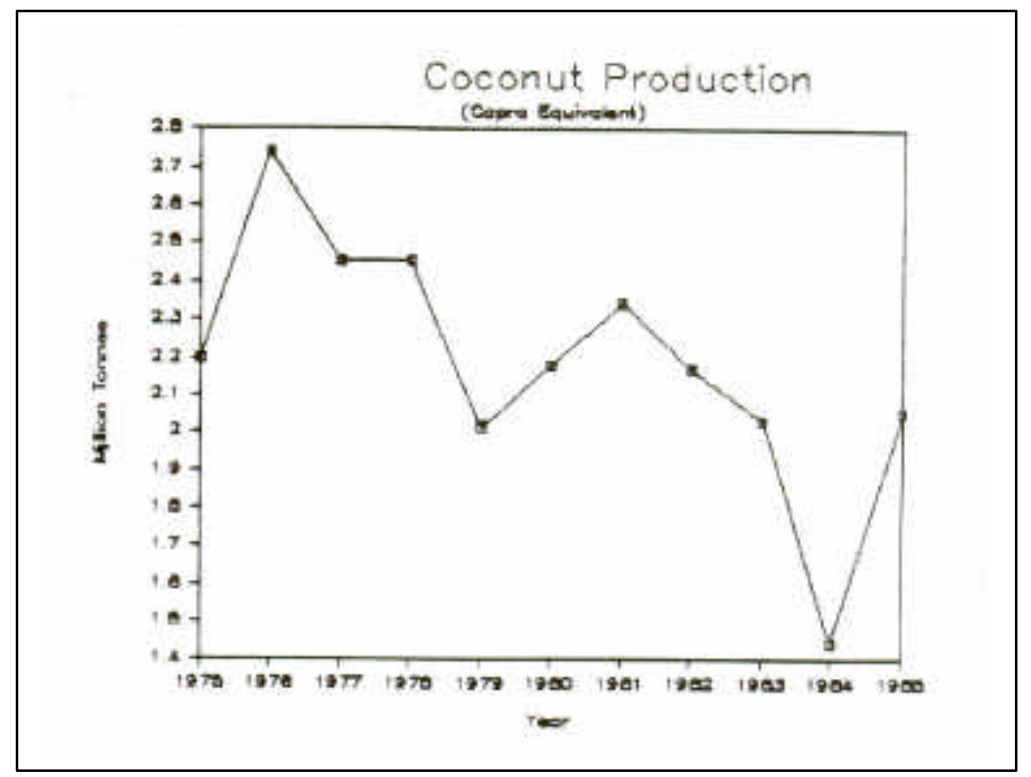

Figure 1. The Philippine Coconut Harvest Sources: UCAP 1986b, 1986c.

Table 1. Grades and Standards for Philippine Coconut Products

\begin{tabular}{|l|l|l|l|}
\hline \multicolumn{3}{|c|}{ COPRA } \\
\hline Moisture & \multicolumn{1}{|c|}{ Food Grade } & Fair Merchantable & \multicolumn{1}{|c|}{ Domestic } \\
Oil & $5 \%$ max. & $8 \%$ max. & $15 \%$ max. \\
FFA (as oleic) & $66 \%$ min. & 60 min. & $58 \%$ min. \\
Appearance of oil & $0.5 \%$ max. & $4 \%$ max. & $5 \%$ max. \\
& White to pale & Brown to dark & - \\
Color of oil & White & Brown & \\
& Yellow, max. & 9 red \& 50 & \\
Extraneous matter & - & Yellow, max. & $1 \%$ max. \\
Other specifications & Edible/good grade; Cut into & $0.75 \%$ max. & - \\
\hline
\end{tabular}

\begin{tabular}{|l|l|l|l|l|}
\hline \multicolumn{5}{|c|}{ COCONUT OIL AND PRODUCTS } \\
\hline & \multicolumn{1}{|c|}{ Crude Oil } & \multicolumn{1}{|c|}{ Cochin Oil } & \multicolumn{1}{|c|}{ RDB Oil } & \multicolumn{1}{|c|}{ Parings Oil } \\
\hline Moisture & $1.0 \%$ max. & $0.2 \%$ max. & $0.1 \%$ max. & Standards \\
FFA (as oleic) & $5.6 \%$ max. & $0.1 \%$ max. & $0.1 \%$ max. & For crude, \\
Color & 75 yellow \& & 10 yellow \& & 10 yellow \& & Cochin, and \\
& 12 red & 1 red & 1 red & Edible oils apply. \\
Saponification value & $250-264$ & $250-264$ & $250-264$ & 251 max. \\
Iodine value & $7.5-10.5$ & $7.5-10.5$ & $7.5-10.5$ & 13.7 \\
Odor & - & Soapy & Odorless & - \\
\hline
\end{tabular}




\begin{tabular}{|l|l|}
\hline \multicolumn{2}{|c|}{$\begin{array}{c}\text { COCONUT ACID OIL } \\
\text { (Acidulated Coco Oil) }\end{array}$} \\
\hline Saponifiable matter & $95 \%$ min. \\
Moisture \& impurities & $2 \%$ max. \\
Iodine value & 17 max. \\
Saponification value & 250 min. \\
FFA (as oleic) & $25 \%$ min. \\
Color & Gardner 12 maximum \\
Acid value & 0.5 max. \\
Hydroxyl value & 7.0 \\
Iodine value & 15.0 max. \\
Water & $0.1 \%$ max. \\
\hline
\end{tabular}

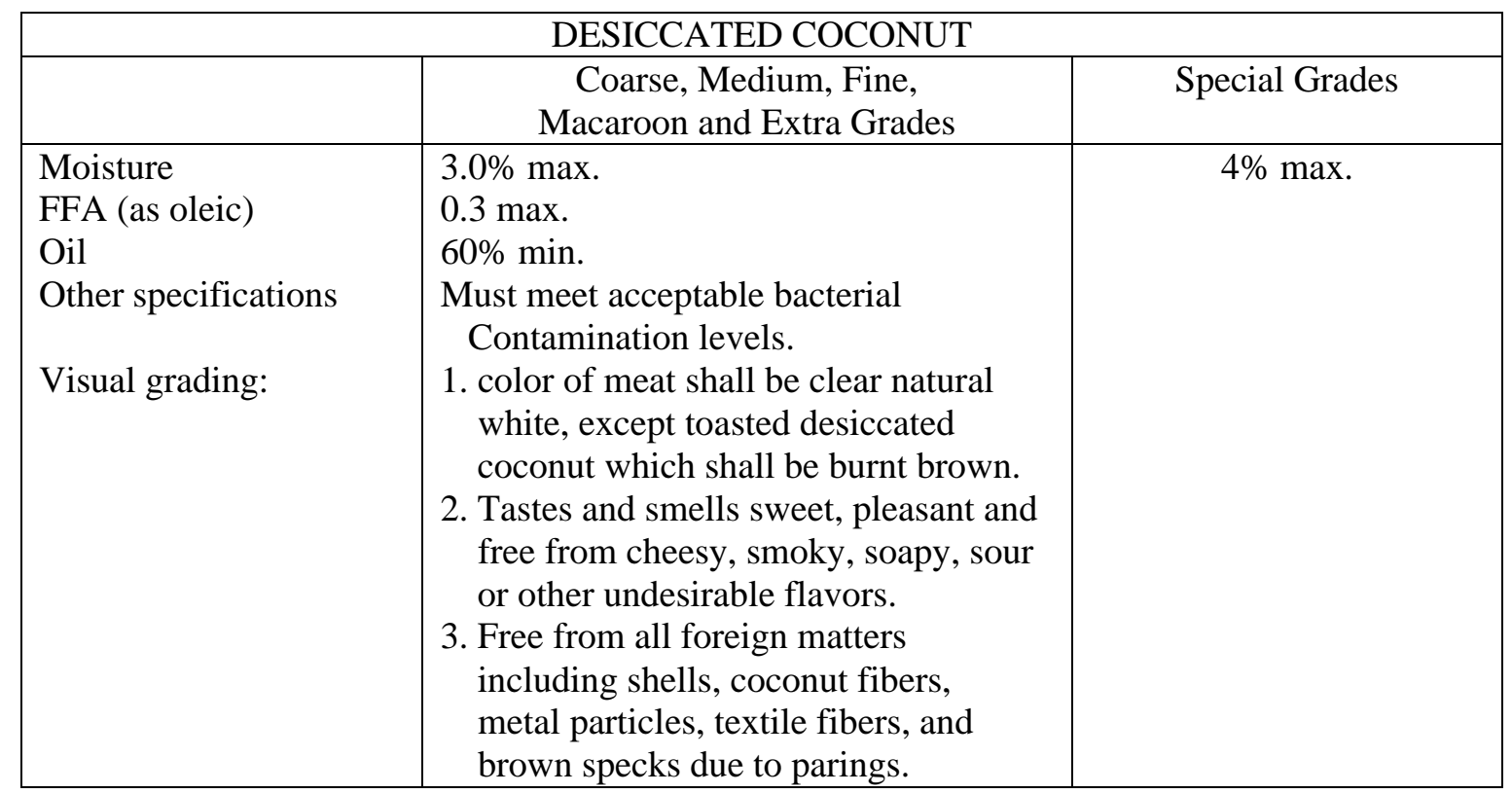

\begin{tabular}{|l|c|c|}
\hline \multicolumn{3}{|c|}{ COPRA MEAL/CAKE PELLETS } \\
\hline & Expeller or Parings & Solvent Cake/ \\
& Cake/Pellets & $12 \%$ max. \\
\hline Moisture & $10 \%$ max. & $5 \%$ max. \\
\hline
\end{tabular}

\begin{tabular}{|l|l|l|l|}
\hline \multicolumn{4}{|c|}{ COCONUT SHELL CHARCOAL } \\
\hline Grade A & \multicolumn{1}{|c|}{$\begin{array}{c}\text { Metallurgical } \\
\text { Grade A }\end{array}$} & \multicolumn{1}{c|}{$\begin{array}{c}\text { Commercial } \\
\text { Grade B }\end{array}$} & \multicolumn{1}{c|}{ Commercial } \\
\hline Fixed Carbon & $80 \%$ min. & $75 \%$ min. & $65 \%$ min. \\
Ash & $3 \%$ max. & $3 \%$ max. & $3 \%$ max. \\
Moisture & $10 \%$ max. & $10 \%$ max. & $10 \%$ max. \\
Volatile combustible matter & $20 \%$ max. & $20 \%$ max. & $20 \%$ max. \\
Sieve analysis & $\begin{array}{l}\text { Not more than 5\% } \\
\text { shall pass a } 1 / 4 \text { inch } \\
\text { mesh sieve. }\end{array}$ & $\begin{array}{l}\text { Not more than 5\% } \\
\text { shall pass a } 1 / 4 \text { inch } \\
\text { mesh sieve. }\end{array}$ & $\begin{array}{l}\text { Not more than 5\% } \\
\text { shall pass a 1/4 inch } \\
\text { mesh sieve. }\end{array}$ \\
\hline
\end{tabular}

Source: UCAP 1986 b. 
In 1985, 77\% of the volume of Philippine coconut products sold was exported (Figure 2). The EEC is their largest buyer with a $32 \%$ share of exports, followed by the U.S. at $31 \%$, and Asia other than Japan at 14\% (UCAP 1986c). The composition of export production changed substantially over the past two decades (Figure 3). The traditional export products are copra, oil, desiccated coconut, and meal/ cake. Copra amounted to $64 \%$ of the export volume in 1965, but had declined to 45\% in 1975 following expansion of the oil milling capacity in the country. Copra exports were banned between September 1982 and March 1986. Some EEC importers prefer to buy copra instead 6f crude oil because they can obtain a higher yield of oil with solvent extraction and also get the byproduct animal feed.

Crude oil rose from 29\% of coconut product exports in 1965 to $83 \%$ in 1985. Although labor costs are lower for processing oil in LDCs than in importing countries, this savings is small because large-scale copra mills are not very labor intensive. However, transport and loading costs ate much lower for oil than for copra and oil is easier to store. Desiccated coconut amounted to $4 \%$ of the exports in both years (UCAP 1986b).

In 1985, 82\% of copra cake/meal was exported (Ibid). Most of the cake/meal is traded in bulk. Importers prefer pelletized cake because the air space between pellets reduces the risk of spontaneous combustion. However, many mills have stopped pelletizing since there is no price premium for this extra step.

The Philippines did not sell cocochemicals abroad until 1979, but that is now the fastest growing segment of the export market. Almost $10 \%$ of the coconuts processed for export went into cocochemicals in 1985 (UCAP 1986c). The main competition for cocochemicals is from petroleum and natural gas products.

\section{Production for Domestic Consumers}

About $23 \%$ of Philippine coconut products sales in 1985 were for the domestic market. Of this amount, food nuts comprised $13 \%$ and homemade oil $8 \%$. Excluding this direct consumption, $76 \%$ of the coconuts marketed domestically went into manufactured cooking oil, $7 \%$ in shortening, $4 \%$ in margarine, $8 \%$ for other food products, and 5\% for laundry or bath soap (Figure 4).

In commodity terms, domestic consumers purchased 133,590 tons of edible oil, 13,867 tons of shortening, 7,336 tons of margarine, 333 tons of desiccated coconut, 171 tons of coconut cream, 7,257 tons of laundry soap, 6,258 tons of bath soap, and 24,031 tons of other products in 1985. In addition, 99,071 tons of copra cake were sold for animal feed. Compared to the previous year, domestic consumption of edible coconut oil rose sharply due to lower prices, while shortening and margarine demand increased at about the same rate as population. Laundry soap sales fell $27 \%$ as synthetic detergents continued to gain, while the market for bath soap grew $22 \%$. Copra cake use skyrocketed due to the bumper crop of coconuts (UCAP 1986c).

Oil consumption is low in the Philippines. In most rural households, total daily fat consumption is $30-40 \mathrm{~g}$ per person, well below the recommended amount of $50 \mathrm{~g}$ per person. Coconut oil is the predominant oil in the Philippine diet. Most rural consumers there prefer refined oil because it is odorless, bland tasting, clear, and clean. By contrast, consumers in Moslem areas of the Philippines want fried foods to have the stronger flavor of crude coconut oil as assurance that lard was not used in cooking (Banzon 1987).

Per capita consumption of edible coconut oil in the Philippines was $2.8 \mathrm{~kg}$ in 1985 , a year of abundant supplies on the domestic market. This was below the 16-year average of $3.2 \mathrm{~kg}$ (UCAP 1986b). The recent decrease occurred because the domestic price controls and subsidies for coconut oil had been cut back and the market share of corn and soybean oils among urban consumers had increased (UCAP 1986b). Onthe other hand, there has been a shift from consumption of shortening 
toward oil (UCAP 1986b). The per capita demand for edible oil is expected to increase with income growth and the total demand is also rising with population growth, which is currently $2.4 \%$ (U.S. Department of State 1986).

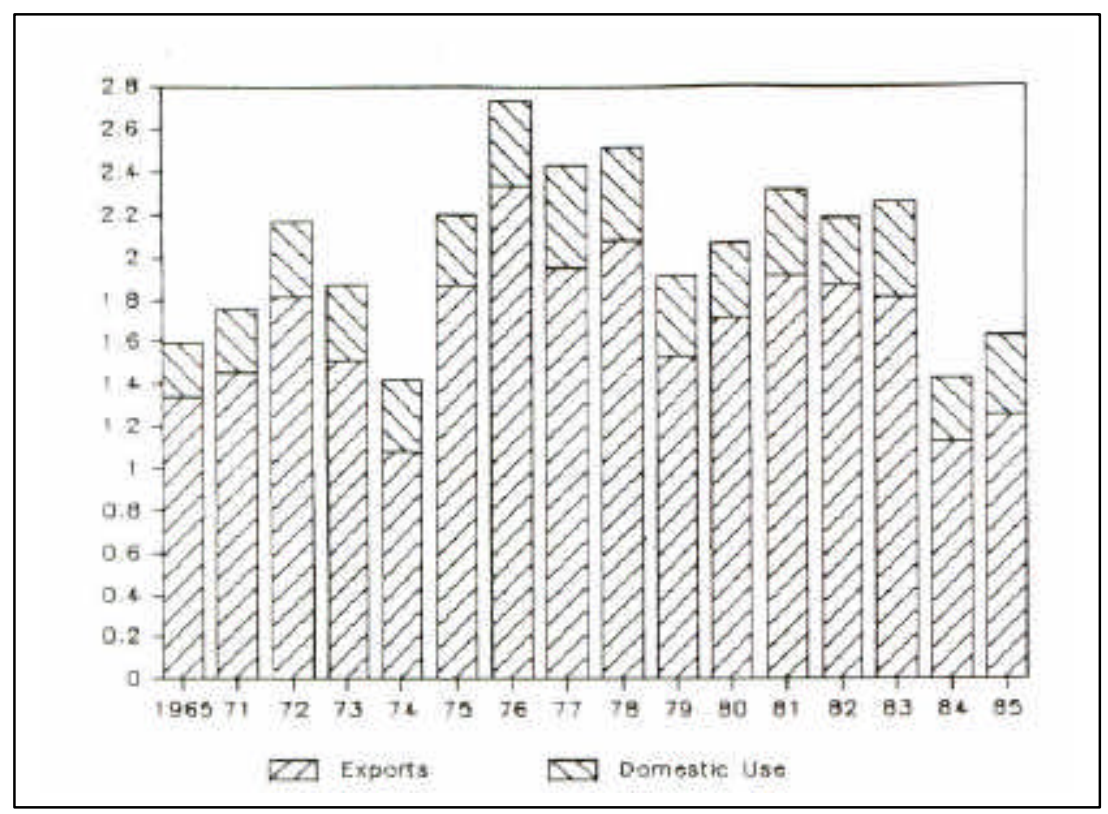

Figure 2. Exports and Domestic Utilization of Coconuts, Philippines (million t of copra equivalent)

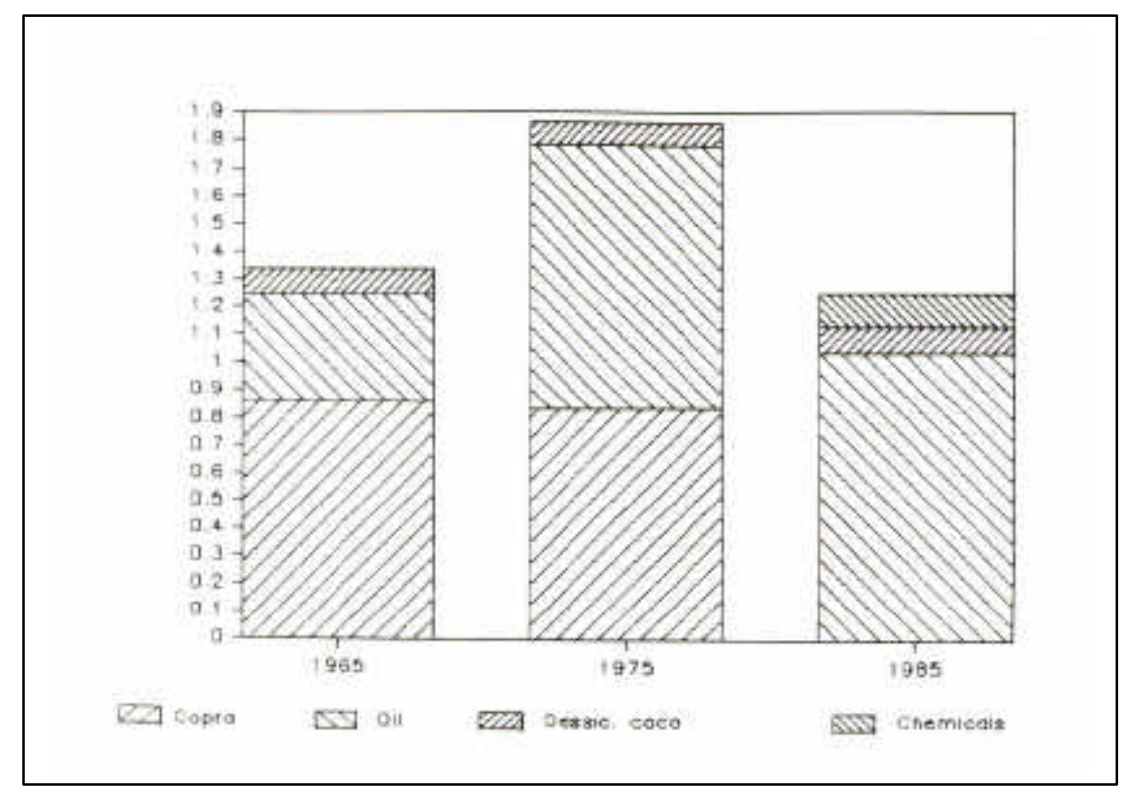

Figure 3. Composition of Coconut Exports,

Philippines (million t Copra equivalent)

Over time, other edible oils may gain a significant, but small' share of the middle-income, urban market due to concern over possible health effects of coconut oil. An oversupply of less saturated, vegetable oils from temperate countries is also expected. However, coconut oil will remain dominant in rural markets due to its lower cost and government policies that will probably attempt to prevent large inroads in urban markets. 


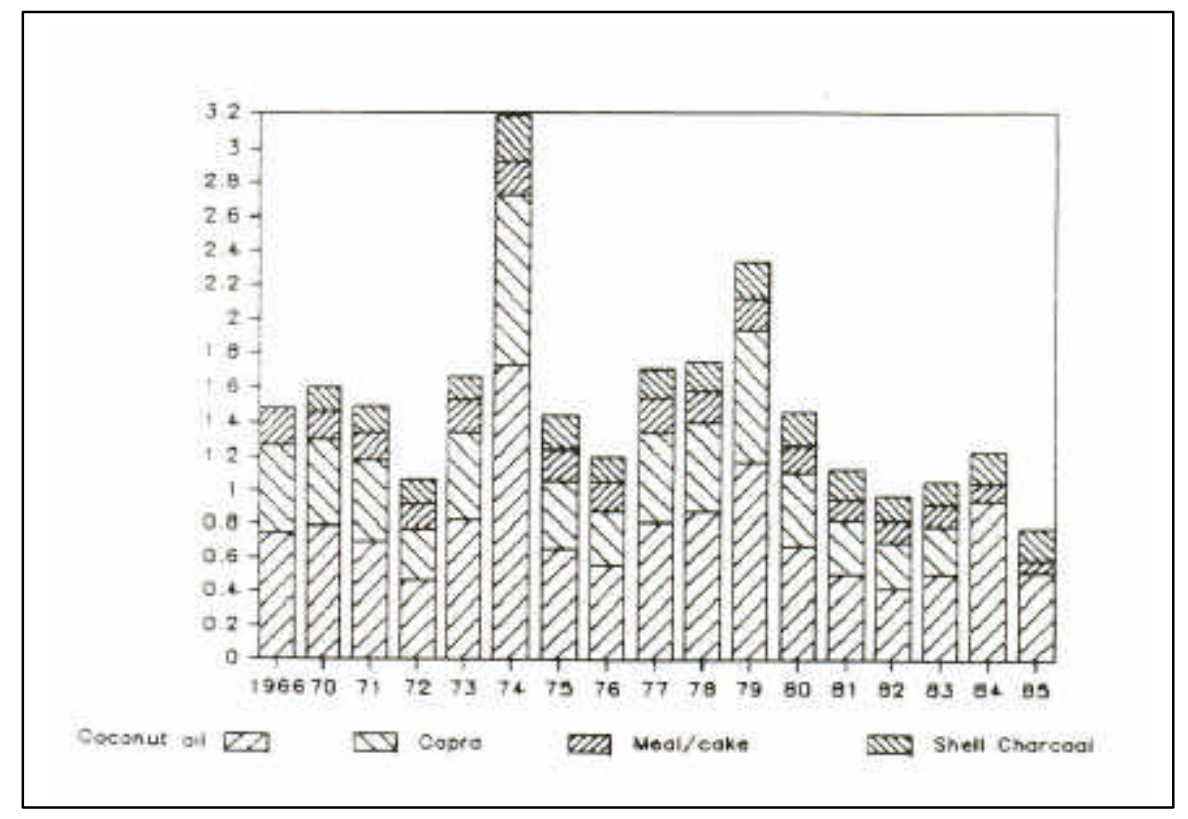

Figure 4. Composition of Domestic Production, Philippines (1000 $\mathrm{t}$ copra equivalent)

Copra expeller cake is less dusty than solvent-extracted meal and more palatable to animals (UNIDO 1977). Although the cake contains 18-25\% protein (Woodroof 1979), it is unsuitable for human consumption because much of the protein is denatured by the high temperatures and in expelling. Furthermore, the unsanitary conditions of copra preparation and storage in the Philippines result in microbial contamination and rancidity of residual oil in the cake. Because copra cake is softer and absorbs water more rapidly than other oilcakes, it does not keep as well (Grimwood et al. 1975). Copra cake should only be a large part of the diet for ruminants because it is too fibrous for other animals (Dendy and Timmins 1973). Nevertheless, smaller quantities may be fed to pigs and chickens. The domestic market for copra cake is mainly for a small number of large users.

Laundry sol

\section{Prices and Susceptibility}

Real unit prices of Philippine coconut exports fluctuated a great deal over 1970-1985. Overall, the trend has been downward as the peaks became lower and the through deeper (Figure 5). Adjusted for changes in the U.S. Producer Price Index for Intermediate Materials, the export price of coconut oil in U.S. dollars has fallen $24 \%$ since 1985 although copra cake prices have risen (UCAP 1986b, 1987; U.S. Bureau of Labor Statistics 1987).

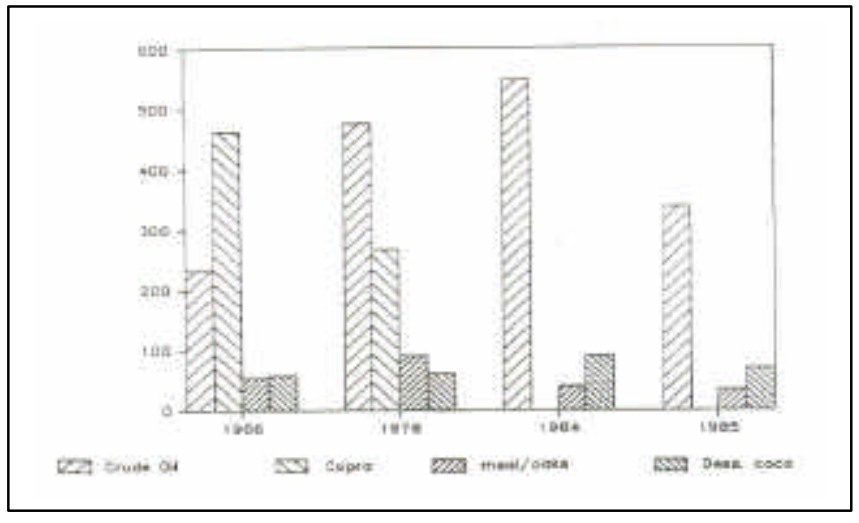

Figure 5. Real Prices of Coconut Exports 
As a result of low prices, the real value of traditional coconut product exports declined to U.S. \$441 million (f.o.b) in 1985 (Figure 6). Traditional coconut products have fallen in relative importance to $10 \%$ of merchandise export earnings in 1985 from $21 \%$ in 1976 . Nevertheless, the value of traditional coconut product export still exceeds that of forest, sugar, or mineral products (UCAP 1986b). Nontraditional coconut products added another $\$ 71.6$ million in export earnings in $1985 ; 72 \%$ of this was from cocochemicals (UCAP 1986c).

The domestic market for coconut products largely reflects world prices. Real domestic prices (adjusted for changes in the Philippine Wholesale Price Index) have oscillated over the period, 1975-1985. Overall, the was downward. as the peaks became lower and the troughs deeper (Figure 7). However, domestic copra prices recovered in 1986 after the lifting of the ban on direct exports of unprocessed copra.

Much of the yearly variation in prices can be explained by fluctuations in harvests. From 1971 to 1985, annual world production of coconut oil ranged between 2.24 and 3.3 million tons, averaging 2.80 million tons (UCAP 1986b). The Philippines is the largest exporter of copra and coconut oil, providing $62 \%$ of the world's traded volume in 1985 . Due to its market share, the size of the Philippine harvest has a major effect on world prices. Because of their cyclical nature, coconut product prices may recover from their current low levels. Nevertheless, real prices may trend downward over the long run due to increases in the world supply of coconuts and substitution of other oils.

World coconut production is expected to increase with an expansion in the planted area and higher yields per tree. Hybrid dwarfs are available that yield 2.18-3.16 tons of coconuts per ha, compared to 0.59-1.61 tons per ha for standard palms. The hybrids also begin bearing after 5-6 years, which is 1-2 years earlier than the existing varieties (Lamothe and Rognon 1986). Following major typhoon damage in 1984, the Philippine government ordered replanting with hybrids and these stands are expected to have a significant effect on national production in the 1990s (UCAP 1986b). Competition from other countries for the export market may also increase.

The world demand for oil varies with the general level of industrial activity. For example, recessions in 1974-75 and 1980 led to price declines for vegetable oils. The demand for coconut oil is also affected by the supply of subtitutes. Total world production of major oils and fats has increased from 39.9 million tons in 1975 to 59.3 million tons in 1985.

Coconut oil offers several advantages in food processing. For example, it has a desirable bland flavor and odor, and resists rancidity from oxidation. Its relatively high melting point and high gloss allow it to be used as a solid coating for confections and baked goods. However, it is low in certain essential fatty acids necessary for human health and has twice the saturated fat of dairy cream (Woodroof 1979).

The price elasticity of demand is high for edible oil because different types of oil are largely interchangeable after processing (UNIDO 1984). Modern food technology has overcome the previous disadvantages of soybean oil such as difficulties in refining, flavor reversion, low extraction efficiency, and susceptibility to rancidity (Banzon 1987). Nevertheless, the demand for coconut oil is more stable than for most other edible oils because it does not require, extensive processing for special uses. 


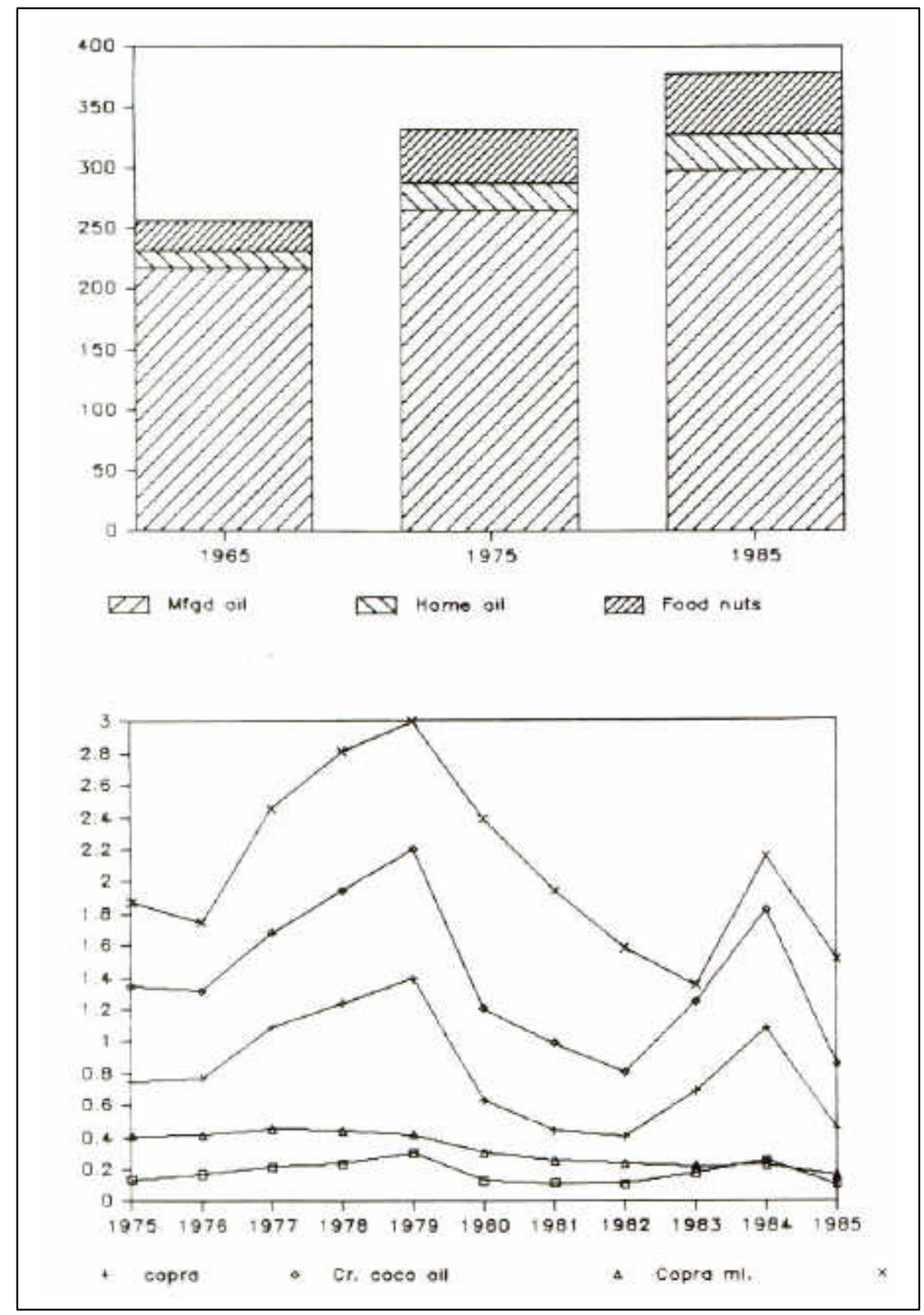

Figure 7. Real Domestic Prices of Coconut Prices of Coconut Products (1985 values, $\mathrm{P} / 100 \mathrm{~kg}$ )

Coconut, palm, and palm kernel oils are the only major vegetable oils with a high content of lauric and myristic acids. Soaps made from these oils are excellent surfactants that foam well even with cool, hard, or saline water. Coconut oil soap lathers easily and has a pleasant aroma, but the lather does not last long and may irritate the skin of sensitive individuals (Thieme 1968). Coconut oil is commonly used in hair care products because it is does not dry out the hair. Coconut oil derivatives have many pharmaceutical uses: a solvent for vitamins; carrier for injections and aerosols; thickening agent for creams, lotions and ointments; and coating for delayed action tablets (Woodroof 1979). In the United States, $57 \%$ of the lauric acid produced is used in soaps; $22 \%$ in rubber, plastics, and elastomers; and the rest in chemicals particularly esters (Jimenez 1986). 
Since the characteristic of specific oils are more critical for industrial applications, the potential for substituting other vegetable oils for coconut oil are more limited. Palm and palm kernel oils are the main substitutes for coconut oil for industrial purposes. In the United States, tallow is the principal source of fatty acids for soap making. Extensive refining has to be done to remove the color and odor of palm oil. However, research is being conducted on other plants such as Cuphea which can yield diverse fatty acids for surfactants, drugs, dyes, and perfumes without fractionation (UCAP 1986a).

World production of competing oils has grown faster than coconut oil (figure 8). As a result, coconut oil's share of world production of major oils and fats fell from $7.8 \%$ in 1976 to $5.0 \%$ in 1985. Research and intensive management have brought about large increases in oil palm yields, especially in Malaysia. Further production gains are expected for palm oil in Malaysia and Indonesia (Hyman 1988 b) and soybean oil in Brazil and Argentina (Banzon 1987).

Coconut oil generally sells at a premium over palm and soybean oils. Palm kernel oil is priced only slightly lower than coconut oil and is subject to similar fluctuations because of its comparable characteristic and uses (figure 9). The size of the premium for coconut oil has been shrinking because improvements in processing technologies have reduced the advantages of coconut oil over other fats.

\section{Effect of Government Policies}

Government policies of importing and producing countries have had a largely negative on the coconut industry. The main exception is tariffs levied in the Philippines on importation of edible oils and oilseeds. The tariff amount is $10 \%$ for soybeans and $60 \%$ for other oilseeds and copra.

Tariffs and trade barriers of importing countries increase the instability of coconut product prices by limiting the international market's ability to absorb bountiful harvests. Tariffs are generally higher for semifinished goods like crude coconut oil than for unprocessed copra. For example, the EEC places a tariff of $25 \%$ on margarine and shortening, $8 \%$ on refined coconut oil for industrial use, and $15 \%$ on edible coconut oil (UCAP 1986b).

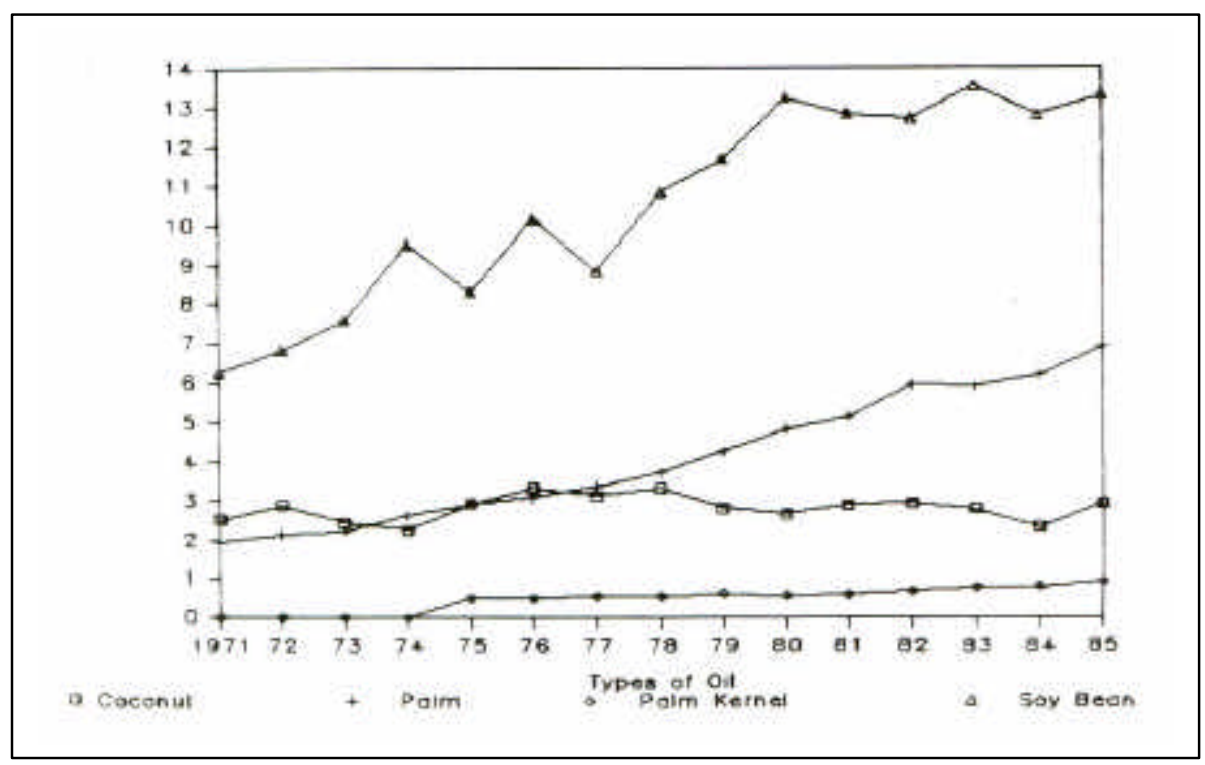

Figure 8. World Production of Coconut Oil and Its Principal Substitutes 
Overly stringent product quality standards also constitute a trade barrier. The EEC has proposed tightening the present aflatoxin in copra from $50 \mathrm{ppm}$ to $20 \mathrm{ppm}$ and setting a standard of $10 \mathrm{ppm}$ for expeller cake from coconut processing (Ibid.). Only one-third of the copra process mills in the Philippines could meet this proposed standard (Jimenez 1987). Also, the EEC has not proposed a strict standard for groundnut byproducts for animal feeds, which are imported from former French colonies in West Africa and arc even more likely to have high aflatoxin levels. Although aflatoxin is serious health risk, it is removed from the oil in refining.

Philippine government policies also effect the export and domestic markets for coconut products. Price ceilings for edible coconut oil were established in March of 1973, lowered in October of 1973, and raised in January and May of 1974 and June of 1978. In 1978, the price ceilings were lifted for bulk oil and the consumer subsidy was limited to households.

As world copra prices rose, the domestic price ceilings led to increased exports of copra in the face a domestic shortage of oil. This shortage and the desire to stimulate the local processing industry resulted in a ban on copra exports in mid-1982. Due to the decline in the coconut industry caused by world market conditions and mismanaged government policies, the copra export ban was lifted in early 1986 to stimulate competition and boost farmgate prices for coconuts. The trade liberalization succeeded in tripling copra prices for farmers, but hurt the domestic mills because coconut oil prices did not rise proportionately.

During the Marcos years, farmers bore several levies on the first domestic sale of copra. The various levies raised the cost of copra for millers and together with price controls on domestic oil reinforced the problems faced by the milling industry.

The first levy, the Coconut Consumer Stabilization Fund (CCSF), was established in 1973 to subsidize domestic consumption and manufacturing of coconut products. It had been as high as P100 per $100 \mathrm{~kg}$ of copra equivalent, but was later reduced to P15 before it was abolished. From 1971 to 1980, there was a Coconut Industry Development Fund (CIDF) levy of P60 per $100 \mathrm{~kg}$ for financing the replanting of coconut lands. The CIDF was replaced by a Coconut Development Projects Fund (CDPF) levy of P55 per $100 \mathrm{~kg}$ of copra. The CDPF levy was imposed on exporters of coconut products and the stated purpose was to purchase coconut planters' banks, mills, and trading companies. Finally, a Coconut Industry Stabilization Fund levy (CISF) was instituted in 1981 for replanting, scholarships, life insurance, and funding of the Philippine Coconut Association arid Cocofeed. The CISF of P50 per $100 \mathrm{~kg}$ of copra was paid directly by exporters and millers.

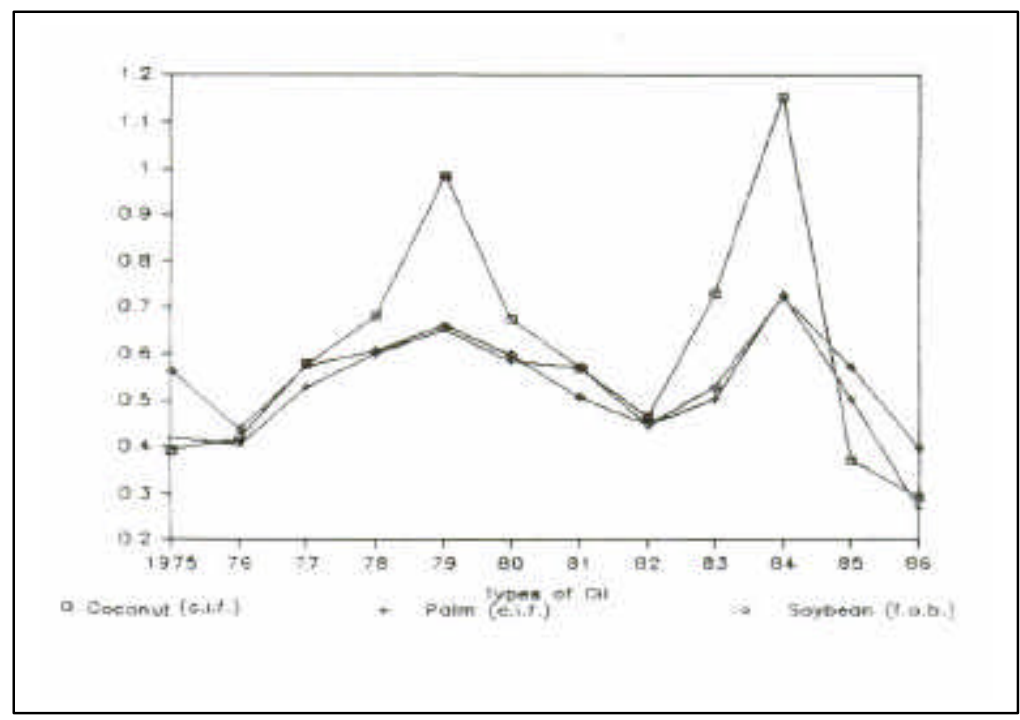

Figure 9. Nominal Prices of Coconut, Palm, and Soybean Oils (U.S. \$/t at European Ports) 
In addition, coconut products were subject to the $9 \%$ export tax on agricultural products prior to 1985 ; this tax was lowered to $5 \%$ in 1985 and eliminated in 1986. In 1981, the export tax on coconut products was removed, but a 7\% export tax was re-established in 1982 just on Copra (Manuel arid Maunahan 1982). Before 1985, there was an additional export duty of $7.5 \%$ on copra, $5 \%$ on coconut oil, and $4 \%$ on Copra meal/cake or desiccated coconut. In 1985, the coconut oil duty was reduced to $11 / 10^{\prime}$ arid the duties on copra meal/cake arid desiccated coconut were removed. There is still a 5\% customs duty on coconut product exports (Jimenez 1987). Oil mills arid exporters are subject to the corporate profit tax of $35 \%$ of net income. Cottage industries with a capitalization of less than P100,000 that ate registered with NACIDA are exempted from the income tax for 5 years. However, even village-scale coconut processing plants are beyond that scale (Hyman 1988 a).

In 1985, many regulations affecting the coconut industry were liberalized. Administrative Order 1 called for reducing government intervention in the marketing of coconut products arid allowed any entity to export them if the foreign exchange proceeds were remitted in accordance with Central Bank regulations. Executive Order (E.O.) 1016 withdrew some inspection, commodity, and export clearance requirements. Presidential Decree (P.D.) 1972 allocated funds from the export duties on coconut products to restart the government's replanting program for coconut farms smaller than 24 ha, especially those devastated by typhoons. P.D. 1997 authorized incentives of up to P30,000 per ha per year for private replanting of coconuts. These incentives could include income tax credits; duty rebates on capital equipment; arid 10-year exemptions from property taxes for land, improvements, arid machinery. E.O. 1075 exempted coconut oil sold to government agencies as a substitute for imported fuel from special fund imposts as well as taxes on millers, manufacturers, sales, and fuels. E.O. 1074 benefited a competing product by exempting 60,000 ha of oil palm plantations from, all taxes, duties and fees.

\section{Cultivation and Harvesting}

Coconut farming requires little labor -- an average of 19-23 person-days per ha per year. Half of this labor is for harvesting, husking, and hauling and much of the rest is for copra preparation (Valiente et al. 1979; Tan 1970). This leaves coconut farmers with a lot of time for off-farm employment, other crops, or livestock. Although land clearing and planting costs are significant, the trees can bear for 60-80 years4 once established. Some weeding is necessary in the early stages of growth, but little cultivation is done unless intercropping is carried out. Fertilizers and pesticides are rarely used. Small farms usually rely on unpaid household sources of labor, but large farms may hire workers on daily basis.

The peak harvest season in the Philippines is August to November and the lean season is during April and May. Farmers usually harvest coconuts every 1-3 months. Coconuts are harvested by cutting them with a knife on a long, bamboo pole; climbing and hand picking; or allowing them to fall to the ground naturally.

For good quality copra, the coconuts should be mature. Copra from immature nuts has more water, less oil and is difficult to dry completely. This gives it a rubbery texture and makes it susceptible to insect attack and difficult to mill (Grimwood et al. 1975). However. to save labor, immature coconuts often are harvested at the same time as a bunch of mature ones. Usually, the immature coconuts are stored for 2-4 weeks before copra preparation to increase their quality and uniformity. Near mature coconuts also benefit from a few days of storage in the shade for easier dehusking and shelling, a lower moisture content, and greater thickness of the meat. Mature coconuts that have fallen from trees may germinate if stored too long. Careful storage of coconuts before copra preparation is important to reduce mold growth, drying out, discoloration, and development of off-flavors; however, coconut farmers in the Philippines generally handle storage poorly. 


\section{Copra Preparation}

Nearly $94 \%$ of the coconut harvest in the Philippines is converted into copra (UCAP 1986c). Production of 1 ton of copra takes 6.28 tons of whole coconuts. Given the average size of coconuts in the Philippines, this requires 5,240 whole nuts, but can range from 3,270 to 10,000 nuts depending on the variety, maturity, and growing conditions (Woodroof 1979).

For the most part, copra is made on the farm using household labor. Although some dry process mills buy whole coconuts and make their own copra, most of the farm gate market is for copra. Copra preparation involves dehusking, shelling, drying, bagging, and storing. These steps are labor intensive, but not very financially rewarding for farmers. Dehusking is generally done manually because mechanical methods are not cost-competitive. By hand, one worker can dehusk 1,000-1,200 coconuts in 8 hours (Dendy and Timmins 1973). Drying should be done immediately after draining to prevent bacterial spoilage that results in discolored copra.

The main drying alternatives for copra are (1) sun drying; (2) smoke curing or direct hot air drying; and (3) indirect hot air drying. Simple, improved methods of copra production at the farm or mill site can produce much better quality copra than the traditional methods at low cost (Lozada 1979).

Sun drying can produce good quality, white copra if done properly. Another advantage is that there is no fuel cost. During the rainy season or in areas of steady rainfall throughout the year, sun drying can be difficult and the copra prone to spoilage. This is a problem in most coconut-growing areas in the Philippines. One solution is to use plastic tents, but this is not often done.

Direct hot air dryers produce copra faster, taking 2-3 days, and can be used in the rainy season. Most serious coconut farmers in the Philippines use this type of dryer. However, direct drying smokes the copra, resulting in poor quality oil and cake. When coconut meat is dried too rapidly at a high temperature, it becomes scorched and the oil extracted from it will be discolored. Or, if the coconut meat is stacked too thickly for good air circulation, the top layers will not dry and the lowest layers undergo "case hardening", which prevents moisture from leaving the interior portions. Since the average moisture content of copra may be as high as $22 \%$ after direct heat drying, further air drying to $10 \%$ or less is necessary in the warehouse before oil expelling at the mill (Banzon and Velasco 1982).

Indirect hot air dryers keep the coconut meat out of contact with combustion gases and smoke so that the copra can be of high quality. This may be accomplished by using blowers for forced, hot air or steam pipes to circulate the heat to a drying rack. Simple, indirect dryers can be easily constructed with prefabricated materials. In more sophisticated models, the coconut meat moves continuously counter to the current of the hot air. The main disadvantage of indirect heating is the higher capital cost, which makes it feasible only for large-scale copra production. Although the energy efficiency may be lower, this is unimportant if a free fuel such as coconut husks is used. Modern commercial dryers operate more quickly, but are usually only economical where there is a market for edible-grade, desiccated coconut (Grimwood et al. 1975).

High-grade copra is uniform, free of dirt, and smooth with a brown outer surface and greyish-white inner surface. The pieces break sharply and are not leathery and the broken edges are white. Most of the copra produced in the Philippines is of poor quality because of the drying techniques and dampness in storage and transport. As a result, bacterial and fungal contamination of copra reduces the oil content and increases the FFA and aflatoxin levels. Copra often has a moisture content of $8-12 \%$ and at these levels, molds flourish and rancidity occurs quickly (Keddie, Allal, and Das 1983). One mold, Aspergillus flavus, can destroy as much as 30-40\% of the oil in copra and increase the FFA of the rest (Banzon and Velasco 1982). In the Philippines, 10\% of the oil in copra is typically lost in storage (Hagenmaier 1980). It is difficult to avoid mold contamination unless copra is quickly 
dried to a 5\% moisture content or chemical treatments are applied (Banzon and Velasco 1982). The Subramanian treatment using alkali and soda has been tried in large-scale copra preparation, but is rarely used now in the Philippines (Jimenez 1987). At present, the market does not provide enough incentive to make it worthwhile to produce high-quality copra for oil milling.

\section{Farmer Incomes From Sales}

Coconuts are an important source of income in 35 of the 73 provinces of the Philippines (Manuel and Maunahan 1982). There were 709,600 coconut farms in 1980 (NEDA 1986). Most arc owner-operated and small; nearly $71 \%$ of them arc less that 5.0 ha (UCAP 1986b).

Over 4 million owner/operators and tenants in the Philippines directly depend on income from coconut farming (Deomampo and Pisigan 1984). Farmers often view long-lived coconut trees as an easy income source for their old age. In addition, many landless laborers find occasional work on coconut farms although this is not a very labor-intensive crop.

Most farmers dehusk their own coconuts and dry the meat into copra before selling it, but a few sell whole coconuts fresh. When farmers have an immediate need for cash, they arc sometimes forced into advance sale arrangements. In 1981, farmers who did not contract to sell copra in advance received an average of $12 \%$ more for their crop (Manuel and Maunahan 1982). Some farmers contract to sell unharvested coconuts off the trees, with the buyer bearing the costs of harvesting and dehusking.

On average, the nearest buyer is, located $4 \mathrm{~km}$ from a coconut farm, but this varies by region. There arc usually 2 or 3 buyers per barrio (Valiente et al. 1979). These buyers may resell. to assemblers or dealers in larger towns or to oil mills; copra exporters; or producers of desiccated coconut, cocochemicals, charcoal and activated carbon, and coir. At the level of assemblers and wholesalers, entry is limited due to high initial costs for storage, transport, and working capital (Tibayan 1983).

The copra marketing system is relatively inefficient due to the dispersion of producers, involvement of several layers of traders, and poor infrastructure (Deomampo and Pisigan 1984). One study found an average gross margin for coconut dealers of $46 \%$ on copra and $35 \%$ on coconuts, about half of that being net profit (Manuel and Maunahan 1982). Some mills buy copra directly from farmers and pay a bit more than the middlemen do.

Prices tend to be low in remote areas where transport costs to distant mills arc high and few buyers compete for the crop. Since most coconut farmers arc small scale, they arc price takers. A bumper crop does not always translate into a good year for coconut farmers unless harvests in another region arc poor because lower prices can offset an increase in the quantity sold.

The classification basis for pricing copra is "resecada" grade with a $6 \%$ moisture content. Resecada copra contains $61.5 \%$ oil, compared to $70 \%$ for completely mature and fully dried copra, and as low as $43 \%$ for poor quality copra subjected to attack by insects, fungus, or bacteria (Jimenez 1987). Because of the lower oil content, buyers pay a lower price for copra with a high moisture content. The average price received by farmers is $12.5 \%$ below the resecada price to account for the moisture content (Manuel and Maunahan 1982). Some buyer also consider deterioration and maturity in setting prices.

Transport costs may be borne directly by the seller, but buyers often pick up the produce from the farm and pay a lower price to compensate for this service. In early 1987, the price of resecada copra at provincial buying stations was P3,700-4,100 per tonne. Mills outside of Metro Manila paid an average of $\mathrm{P} 4,120$ per ton delivered to their warehouses. Traders who delivered copra to mills in Manila received P4,700 per ton, a gross margin of 15-27\% (UCAP 1987). 
Given the typical density of 126 trees per ha and the average annual yield of 30 coconuts per tree. 1 ha produces 3,780 nuts a year. This harvest can be converted into 0.721 tons of non-resecada copra and sold for P2,330-2,590 at provincial buying stations. A farmer with 2.5 ha of coconut trees would earn a gross annual income of at least P5,825 from the sale of copra. Farmers with high-yield varieties of coconuts could earn twice that much. The net cash returns almost equal the gross returns because of the low cash costs of raising coconuts.

The typical income from sale of copra is below the national per capita income. However, most coconut farmers have additional income from crops planted on other land or from interplanting between coconut trees. Although intercropping is becoming more common, it has only been done on a small portion of coconut land -- 12\% in the Southern Tagalog region (Olalo 1975) and 39\% in part of Laguna province (Pujanes 1978).

The price of whole coconuts is derived from the copra price less the value of the time saved in copra preparation and the extra transport costs for whole nuts. The value of household labor time depends on how productively it is used by the household. Large-scale farmers who hire workers pay labor costs of P0.1 per coconut for copra preparation, which would total P375 per ha per year.

\section{Scale and Location of the Processing Industry}

The ILO classified coconut mills by maximum annual quantity of raw materials processed: "village-scale" -- less than 1,050 tons, "small" -- 1,050-2,400 tons, "medium" -- 2,400-6,000 tons, and "large" -- greater than 7,500 tons. Large- and medium-scale mills have to be run at a high capacity use rate to be commercially viable because of their high capital costs. Large mills are intended to operate 24 hours per day for 300 days per year. Small mills typically operate 8 hours per day, 250 days per year. Since obtaining a sufficient supply of coconuts for a large mill can be a problem, these mills are generally located in urban areas with good transportation infrastructure. The cost and reliability of power is another major factor in mill location decisions, favoring areas with abundant hydroelectric or geothermal power. Large and medium-scale mills also require higher levels of managerial skills. In mid-1986, 43 commercial milling units were operating in the Philippines, including 16 in the Southern Tagalog region, 13 in Mindanao, 8 in Metro Manila, 4 in The Visayas, and 2 in the Bicol. They provided a total crushing capacity of 3.63 million tons of copra per year -- the equivalent of 2.27 million tons of crude coconut oil. Mindanao had $47.3 \%$ of the copra crushing capacity, the southern Tagalog region had 18.8\%, Metro Manila had 16.8\%, the Visayas had 9.5\%, and Bicol had 7.6\% (UCAP 1986b). Most mills in the Philippines sell crude oil on forward sales contracts, but a few trading companies lease mills.

The operating mills have capacities between 7,500 to 300,000 tons of copra per year (UCAP 1986b). All of these mills are large by the ILO definition. The mean capacity is 84,000 tons per year, and the median is 66,000 tons per year. The mean exceeds the median because of a few very large plants. The plants in Mindanao tend to be relatively large and the ones in the Southern Tagalog region relatively small.

Alviar's (1982) model concluded that it would be optimal to have only 35 coconut mills having half the then current total capacity. Although the model recommended fewer mills in the Southern Tagalog region and Mindanao, it suggested the need for more mills in the Visayas. The model implied an optimal, average capacity of 42,000 tons per year.

Only three Philippine mills rely on solvent extraction for copra process oil; the rest use imported, large, continuous expellers. Three-quarters of the mills have Anderson Superduo expellers (U.S.), but a few have large expellers made by Krupp (Germany), Rose-Down Thompson (U.K.), or D-Smet (Germany). The Superduo has a rated capacity of 1.0 tons of copra per hour. A median-sized mill in the Philippines would have nine large expellers, while most small, commercial mills would 
have only one. Keddie, Allal, and Das (1983) stated that the smallest economical capacity for a conventional expeller mill operating on a single shift is 3.33 tons per day. However, smaller motorized expellers are available.

The capacity use rate for the Philippine copra milling industry has averaged $60 \%$ between 1970 and 1985, but was only $40 \%$ during the last year of that period (UCAP 1986b). This rate is based on triple shifts for medium- and large-scale mills. When a single large oil mill is built or expanded, the industry's capacity increases substantially. Once established, government restrictions previously made it difficult for large firms to enter or exit the industry. Over the past 15 years, some of the smaller mills closed after being bought out by government monopolies. Also, some larger mills were abandoned or taken over by banks (Banzon 1987).

Small-scale mills usually run single shifts per day, but can operate at a higher proportion of that capacity. Small mills may be decentralized for a better match between local supply and demand for oil and other products such as soap. They can also be installed in modules to allow for gradual future expansion. A small mill is particularly desirable for islands or remote areas where farmers have difficulty marketing coconuts or are offered very low prices. In these areas, consumers generally pay relatively high prices for coconut oil and soap due to greater transport costs, a larger number of intermediaries involved in distribution, and lower volumes of purchase by local retailers. Production costs may also relatively low for decentralized coconut oil mills due to lower wage rates and reduced transport costs for raw materials and the final product. However, any transport cost advantage may be lost if the oil has to be shipped out for refining and back in for sale.

Crude oil from the copra process has to undergo, extensive refining before it meets the specifications for edible oil on the domestic market in the Philippines. The country has sixteen mills that do some of their own refining. These firms have a total refining capacity of 833,500 tons of crude oil per year. In addition, nine other firms that only do refining have, a capacity of 347,000 tons of crude oil per year. The domestic refining capacity is 1.18 million tons of crude coconut oil per year, $32 \%$ of the milling capacity (UCAP 1986b). Typically, 5\% of the crude oil is lost in refining.

\section{Implications}

At present, the coconut industry in the Philippines is adversely affected by low product prices and high input costs. Nevertheless, coconut oil production and refining are still profitable at this scale. However, commercial prospects for village- and small-scale copra process plants are not good, given the current state of the technology.

With proper selection of equipment and a high capacity use rate an alternative technology, a village-scale wet process, could be economically viable where it does not compete with the products of large-scale industry. The main justification for choice of the wet process is the potential for additional byproducts, but further product development and testing is needed there (Hyman 1988 a).

Note: This article was submitted to CORD in January 1989.

\section{ACKNOWLEDGMENTS}

The author would like to thank Paul Bundick (ATI) for his assistance in arranging this study and the late Julian Banzon (then Professor Emeritus, University of the Philippines at Los Banos), Marita Cuano (Filipinas Foundation), and Arturo Jimenez (Consultant to the Filipinas Foundation) for providing essential data. Helpful comments on this draft were received from Paul Bundick, Mike O'Donnell, and Glenn Patterson of ATTI. 


\section{REFERENCES}

ALVIAR. M. 1982. Optimum Number, Size, and Location of Coconut Oil Mills in the Philippines. Los Banos: University of the Philippines, Master's thesis.

BANZON, JULIAN (Consultant). 1987. Personal communication.

BANZON, JULIAN and JOSE VELASCO. 1982. Coconut Production and Utilization. Manila: Philippine Coconut Research and Development Foundation.

DENDY, D. and W. TIMMINS. 1973. Development of Wet-Coconut Process Designed to Extract Protein and Oil from Fresh Coconut. London: Tropical Products Institute.

DEOMAMPO, N. and C. PISIGAN. 1984. "State of the Art Coconut Economics Research." Presented at the Symposium on Coconut Research and Development. Los Banos: Philippine Council for Agriculture and Resources Research.

GRIMWOOD, BRIAN et al. 1975. Coconut Palm Products: Their Processing in Developing Countries. Rome: FAO.

HAGENMAIER, ROBERT. 1980. Coconut Aqueous Processing. Cebu City, Philippines: University of San Carlos Publications.

HYMAN, ERIC, 1988 (a) The Choice of Technology and Scale in Coconut Processing in the Philippines. Washington, D.C. Appropriate Technology International

HYMAN, ERIC, 1988 (b) The Range of Choice in Palm Oil Processing Technologies for Cameroon. Washington, D.C. Appropriate Technology International

JIMENEZ, ARTURO (Consultant). 1987. Personal communication.

JIMENEZ, RUDOLFO. 1986. "Oleochemicals -- Improving Utilization of Coconut Oil." Coconuts Today, Vol.4, No. 1:56-64.

KEDDIE, J.; M. ALLAL; and A. DAS. 1983. Small-Scale Oil Extraction From Groundnuts and Copra. Geneva: International Labor Office, Technology Series, Technical Memorandum No. 5 .

LAMOTHE, M. and F. ROGNON. 1986. "A Choice Based on Results: Hybrids or Talls. " Coconuts Today, Vol. 4, No. 1: 69-76.

LOZADA, ERNESTO. 1979. "The UPLB Copra Dryer." Manila: Proceedings of the Fifth Session of the FAO Technical Working Party on Coconut Production, Protection, and Processing.

MANUEL, P. and M. MAUNAHAN. 1983. Coconut/Copra Marketing System -- Structure, Conduct and Performance. Los Banos: Philippine Council for Agricultural Resources Research and Development

NEDA 1986. 1986 Philippine Statistical Yearbook. Manila: National Economic and Development Authority

NSTA, 1985. Laundry Bar Soap From Coconut Oil. Manila: National Science and Technology Administration 
OLALO, C. 1975. An Analysis of Resource Productivity and Credit Needs of Coconut Farmers in Southers Tagalog. Los Banos: University of the Philippines. Undergraduate thesis.

PUJANES, O. 1978. Farm Management Study of Inter-cropped Coconut Farms in Alaminos, Laguna. Los Banos: University of the Philippines, Undergraduate thesis.

SANTOS, G. 1986. "State of the Art: Coconut Production in the Philippines." Coconuts Today, Vol. 4, No 1: 77-86.

TAN, V. 1970. Farm Management Analysis of Selected Coconut Farms in Cantilan. Surigao del Sur. Los Banos: University of the Philippines, Undergraduate thesis.

THIEME, J. 1968. Coconut Oil Processing. Rome: Food and Agriculture Organization of the United Nations, Agricultural Development Paper No. 89.

TIBAYAN, A. 1983. Market Structure, Conduct and Performance of Copra Marketing System in Selected Towns of Bicol Region. Los Banos: University of the Philippines, Master's thesis.

UCAP. 1986a. Concept Paper for a Coconut Industry Development Strategy. Manila: United Coconut Association of the Philippines.

UCAP. 1986b. Coconut Statistics Annual, 1985. Manila: United Coconut Association of the Philippines, Vol. VI, No. XIX.

UCAP. 1986c. "1985 Statistics" Coconuts Today, Vol. 4, No. 1: 117-153.

UCAP. 1987. Weekly Bulletin, Vol. 22 No. 9 (March 5, 1987).

UNIDO. 1977. Guidelines for the Establishment and Operation of Vegetable Oil Factories. New York: United Nations Industrial Development Organization.

UNIDO. 1984. The Vegetable Oil and Fats Industry in Developing Countries. United National Industrial Development Organization, Sectoral Studies Series No. 13, Vol. 1, Vienna: New York.

U.S. BUREAU OF LABOR STATISTICS. 1987. Producer Price Indexes. Washington, D.C.: U.S. Department of Labor.

U.S. Department of State, 1986. Background Notes: Philippines. Washington, D.C.: Government Printing Office

VALIENTE, A. et al. 1979. Coconut Socio-Economic and Marketing Study. Quezon City: Ministry of Agriculture.

WOODROOF, JASPER. 1979. Coconuts: Production, Processing, Products. Westport, CT: Avi Publishing Co. 